\title{
A new ferric iron reducing assay for evaluation total antioxidant activity of food and biolog-
}

\section{ical samples}

\section{Parisa Sadighara ${ }^{1 *}$}

'Department of Environmental Health Engineering, Food, Division, School of Public Health, Tehran University of Medical Sciences, Tehran, Iran

\section{*Correspondence to:}

Dr. Parisa Sadighara

sadighara@farabi.tums.ac.ir

Received: 29 January 2020

Accepted: 07 April 2020

ePublished: 16 June 2020

Keywords: Antioxidant activity Food and biological samples,

Oxidative stress

\section{Citation:}

Sadighara P. A new ferric iron reducing assay for evaluation total antioxidant activity of food and biological samples. Plant Biotechnology Persa. 2020; 2(1): 14-15.

Abstract
Various methods have been developed in recent years to evaluate the total antioxidant
activity of food and biological samples. In this study, a new ferric iron reducing assay was
applied for measuring total antioxidants. This method is based on the oxidation on the
reducing the iron III to iron II. The extraction was incubated with Fecl3 and KSCN. Ferric
thiocyanate complex is formed in an acid solution. This complex is measured at $474 \mathrm{~nm}$.
A lower absorbance indicates increased reducing power.

\section{Dear Editor,}

Oxidative stress results from excessive levels of reactive oxygen species (ROS). ROS induce oxidative stress. It damage to macromolecule such as DNA, lipids, proteins, carbohydrate. Lipids are the major component of food. ROS attack polyunsaturated fatty acids and cause lipid peroxidation. Therefore, to prevent these damages, sufficient amount of antioxidants need to be added to foodstuff. The synthetic of antioxidant commonly use in food that their safety has been questioned [1]. Potential sources of antioxidant component have been searched in several type of natural material such as vegetable, fruits, leaves, herbs, seeds, and roots which could be replaced synthetic antioxidant in foodstuff. There are many methods are available to determine antioxidant activity. Moreover, different markers of oxidative damages to molecules can be assay by these methods. But these experiments needs specific reagent. Instance, in other procedures such as FRAP involve the reagent TPTZ [2] or in The CUPRAC assay, Neocuproine is used as reagent [3]. This work is considered to be useful tool for assessment of antioxidant activity without needs specific reagent.

\section{Procedure: Fecl3/ KSCN Test}

The proposed reaction is shown in Formula 1.

1. A $0.001 \mathrm{M}$ solution of Fecl3 and $0.06 \mathrm{M}$ solution of KSCN were prepared. The solutions were made up to volume with distilled water. $0.001 \mathrm{M} \mathrm{Fecl} 3$ is sufficient for giving enough $\mathrm{Fe}$ ions. A further of Fecl3 increase absorbance.

2. $0.5 \mathrm{~mL}$ of samples was incubated with $0.5 \mathrm{~mL}$ of Fecl3 and $1 \mathrm{~mL}$ of KSCN.

3. Then add $1 \mathrm{~mL}$ of $\mathrm{HCl} 1 \%$.

4. 30 minutes wait to stabilize color. Further increase in the time does not cause any change in color intensity.

5. The intensity of the colored species is measured using a spectrophotometer. This complex is measured at $474 \mathrm{~nm}$. A lower absorbance indicates increased reducing power. The iron II ions can't react with KSCN to form colored complexes.

$\mathrm{FeCl} 3+3 \mathrm{KSCN}=\mathrm{Fe}(\mathrm{SCN}) 3+3 \mathrm{KCl}$

Formula 1 . The suggested reaction pathway between Fe

Iron III ions in the samples are reduced to iron II with the reducing agent. This reaction depended to antioxidant capacity in samples. Iron III ions and potassium thiocyanate in an acidic solution form a red colored species, Ferric thiocyanate.

Collectively, Fecl3/ KSCN Test is accessible, simple, cost-effective, less time consumption, and excellent alternative source for lipid peroxidation evaluation for screening compounds with antioxidants potent in foodstuff. It can be used for monitoring of exposure to chemical

Copyright (c) 2020 The Author(s). This is an open-access article distributed under the terms of the Creative Commons Attribution License (http://creativecommons.org/licenses/by/4.0), which permits unrestricted use, distribution, and reproduction in any medium, provided the original work is properly cited. 
and pollution in biological samples. Therefore, this assay could identify antioxidant statues and antioxidant defence.

\section{Authors' contribution}

All authors contributed equally to the manuscript.

\section{Conflicts of interest}

The authors declared no competing interests.

\section{Ethical considerations}

Ethical issues (including plagiarism, data fabrica $\neg$ tion, double publication and etc.) have been completely ob $\neg$ served by author.

\section{Funding/Support}

None

\section{References:}

1. Koksal E. Gulcin I. Antioxidant activity of caufiflower. Turkish J Agricul. 2008; 32:65-78.

2. Hu ML, Dillard CJ. Ferric reducing antioxidant assay. Meth Enzymol. 1994; 292: 15-27.

3. Apak R, Guclu K, Ozyurek M, Celik SE. Mechanism of antioxidant capacity assays and the CUPRAC assay. Microchimica Acta. 2008; 160:413-419. 